
\title{
J. Perinat. Med. Dip area in fetal heart rate and its relationship to acid-base-observations
4 (1976) 271 of fetus and mother during labor
}

\author{
Wolfgang Künzel, Michael Cornely
}

Frauenklinik der Medizinischen Hochschule Hannover

The decrease in fetal heart rate which is seen occasionally in late pregnancy and especially during labor is usually related to uterine contractions. Since the fall in heart rate is associated with fetal hypoxia $[2,5]$ an attempt was made to use the dip area (DA) for predicting fetal condition. Dip area was related to the $\mathrm{pH}$ in the umbilical vein [9] and to one scalp blood sample taken after measuring DA [8]. Neither the $\mathrm{pH}$ in the umbilical vein gives a reliable index for fetal condition nor one scalp blood sample can indicate the changes in $\mathrm{pH}$ and $\mathrm{BE}$ which are expected during the presence of deceleration. This can only be a vague approximation describing the relationship of DA and acid base observations. Maternal $\mathrm{P}_{\mathrm{CO}_{2}}$ and blood lactate transfer from mother to the fetus and reverse as shown by KASTENDIECK and MoLL [4] in animal experiments can influence the fetal $\mathrm{pH}$ and base excess. Maternal acid base observations were never studied in connection with DA. In previous experiments [3] we have already undertaken an attempt to quantify the relationship between dip area measured by planimetry and the decrease in base excess i.e. the difference in base excess of the scalp blood and the umbilical arterial blood measured during the respective time.

The present experiments are concerned with the relationship of the fall in fetal base excess and dip area during the first stage of labor and the influence of the change of maternal base excess upon fetal base excess.
The present results reveal a relationship between the dip area of fetal heart rate and the decrease in base excess for the first stage of labor which is similar to that of the second stage of labor, if the same dip-area is measured. The metabolic parameters in the maternal blood seem to influence the base excess of the fetal blood.

\section{Patient material and methods}

The study comprises 39 women during labor. The gestational age was 40.4 weeks (SD 1.1) and the time of labor 7.7 hours (SD 4.7). The babies were delivered 37 times by spontanous delivery and in one case a vacuum extraction and in one case a caesarean section was performed. In 35 cases the APGAR score was 8 and more, in 3 cases 7 and in one case 6 . The weight of the babies was $3450 \mathrm{gr}$ (SD 460) and the weight of the placenta was $530 \mathrm{gr}$ (SD 123). Scalp blood was sampled and analyzed for $\mathrm{pH}, \mathrm{P}_{\mathrm{CO}_{2}}$ and $\mathrm{BE}$ as previously described by WULF, KüNZEL and LeHMANN [10]. The $\mathrm{pH}$ was measured with a commercial pH-meter (RADIOMETER Copenhagen) and the SIGGAARD-ANDERson-Nomogram (1962) was used for base-excess (BE) and $\mathrm{P}_{\mathrm{CO}_{2}}$ determination. Blood was collected simultanously from the hyperemized earlobe of the mother using FinAlgoN ${ }^{\circledR}$ and analyzed for the same parameters. In both no attempt could be made to correct the $\mathrm{BE}$ values according to the actual oxygen saturation because no oxygen 
saturation was measured. In 30 cases blood was collected from the fetal scalp in a definit time interval (60 min (SD2)) during the late first stage of labor. This stage is defined by the dilatation of the cervix which was by the first sample $5 \mathrm{~cm}$ (SD 2) and by the second sample $-60 \mathrm{~min}$. later $7 \mathrm{~cm}$ (SD 2). In 20 cases it was possible to collect umbilical cord blood immediately after birth before the first cry of the baby: umbilical vein and umbilical arterial blood respectively, within 1 hour following the last scalp blood sample. This time is defined as the second stage of labor.

Fetal heart rate (FHR) was continously monitored throughout labor until the fetus was delivered. A needle electrode was placed in the fetal scalp and a commercial equipment for recording FHR beat'to-beat (Hewlett PACKARD) was used. Fetal heart rate was recorded with a paper speed of $1 \mathrm{~cm} / \mathrm{min}$. on HP-recording paper. The dip-areas, regardless of their type, were measured by planimetry (Planimeter, OTT) for the above mentioned time interval where also acid base observations were done. The measured dip area is given in $\mathrm{cm}^{2}$ and in $\mathrm{cm}^{2} / 10 \mathrm{~min}$., respectively. The last term is used for comparing the dip area of different stages during labor.

\section{Results}

2.1 Dip area and acid base balance of fetus and mother during the first and second stage of labor

In Tab. I the acid base parameters of the mother as well as the dip area (DA) and the baseline FHR for the first stage of labor are listed.

During the first stage of labor there was between the two samples taken from the fetal scalp no significant decrease in $\mathrm{pH}: 7.36$ (SD 0.04) and 7.35 (SD 0.05), respectively and in $\mathrm{P}_{\mathrm{CO}_{2}}: 39 \mathrm{mmHg}$ (SD 5) and $39 \mathrm{mmHg}$ (SD 6), respectively. The small drop in B.E. from - $3.0 \mathrm{meq} / \mathrm{l}$ (SD 2.0) to - $3.8 \mathrm{meq} / 1$ (SD 2.6) was also not significant. During this time a dip area of $5.7 \mathrm{~cm}^{2}$ (SD 6.5)

Tab. I. Fetal and maternal acid-base parameter during the first stage of labor:

The $\mathrm{pH}, \mathrm{P}_{\mathrm{CO}}$, and base excess in the fetal blood (hyperemized scalp blood) and maternal blood (capillary blood from the hyperemized earlobe), the dip area of fetal heart rate and baseline fetal heart rate, ( $\overline{\mathrm{x}}=$ mean, $\mathrm{SD}=$ standard deviation, $\mathrm{n}=$ number of cases).

There was no statistical significant difference between the observed parameters (WILCOXON-test).

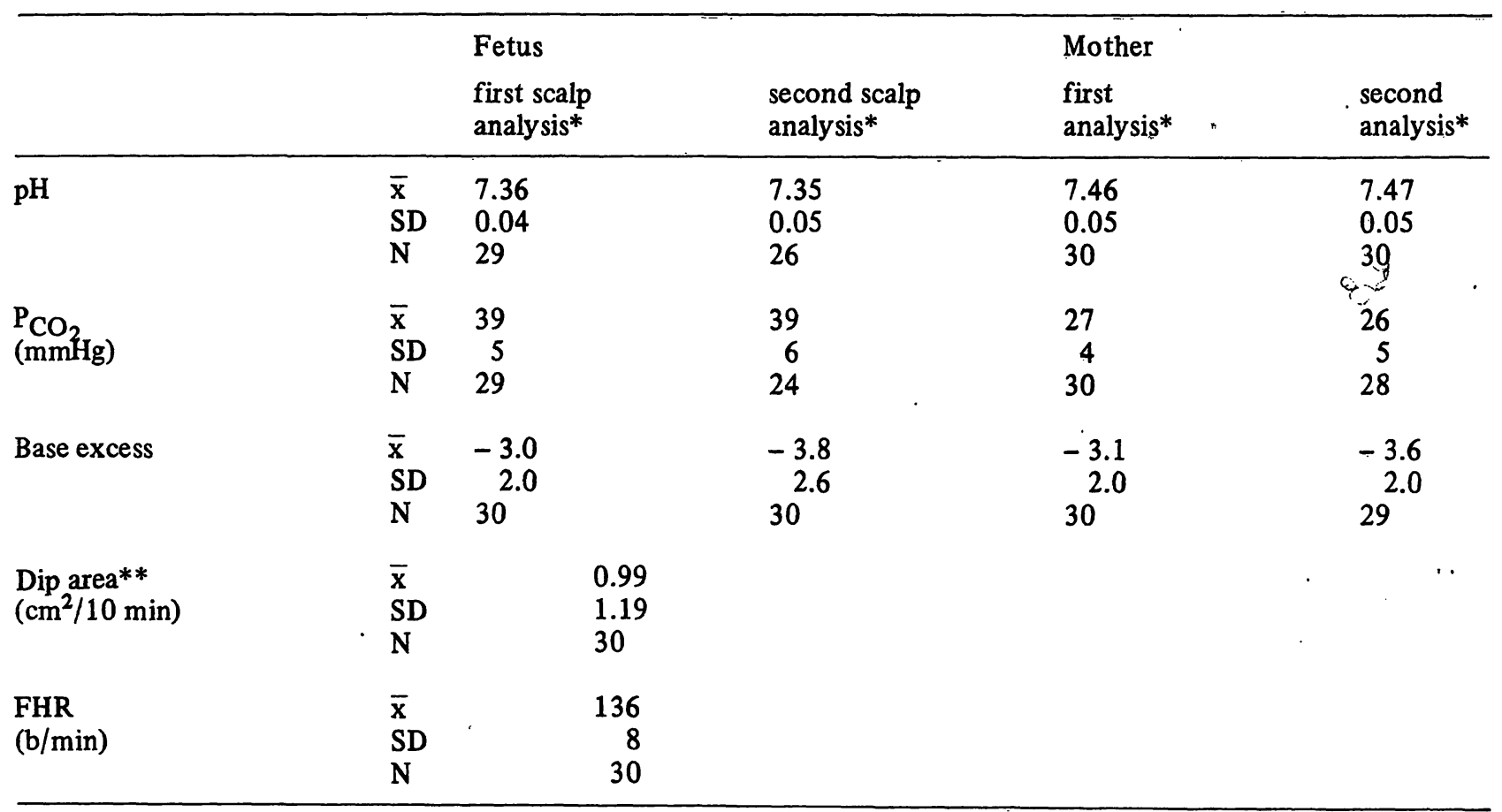

* with FINALGON ${ }^{\circledR}$ hyperemized scalp and earlobe blood (capillary blood) respectively

** according to a record speed of $1 \mathrm{~cm} / \mathrm{min}$ on HEWLETT-PACKARD recording paper. 
which equals a DA of $0.99 \mathrm{~cm}^{2} / \min$ (SD 1.19) could be estimated. The baseline fetal heart rate was $136 \mathrm{~b} / \mathrm{min}$ (SD 8).

The acid base balance in the maternal blood remained during the time of observation almost unchanged: The $\mathrm{pH}$ was 7.46 (SD 0.05) and 7.47 (SD 0.05), respectively, $\mathrm{P}_{\mathrm{CO}_{2}}: 27 \mathrm{mmHg}$ (SD 4) and $26 \mathrm{mmHg}$ (SD 5), respectively and the base excess - $3.1 \mathrm{meq} / 1$ (SD 2.0) and - $3.6 \mathrm{meq} / \mathrm{l}$ (SD 2.0).

The fetal and maternal acid base parameters for the second stage of labor are listed in Tab. II.

The time between the last blood sample and the delivery of the baby ranged from 10 to $73 \mathrm{~min}$ (mean $41 \mathrm{~min}$ ) (SD 19). During this time the fetal $\mathrm{pH}$ dropped from 7.37 (SD 0.03) to 7.29 (SD 0.05) $(2 \alpha<0.01)$; there was a small but significant in- crease in $\mathrm{P}_{\mathrm{CO}_{2}}$ from $39 \mathrm{mmHg}$ (SD 4) to $43 \mathrm{mmHg}$ (SD 7). $(2 \alpha<0.05)$ and the base excess fell by $2.8 \mathrm{meq} / 1$ (SD 1.9) from - $3.3 \mathrm{meq} / \mathrm{l}$ (SD 1.7) to $-6.1 \mathrm{meq} / 1$ (SD 2.3) $(2 \mathrm{P}<0.01)$.

In the maternal blood there was also a significant fall in base excess from - $3.4 \mathrm{meq} / \mathrm{l}$ (SD 1.5) to - $5.7 \mathrm{meq} / \mathrm{l}(\mathrm{SD} 2.0)(2 \mathrm{P}<0.01)$, the small drop in $\mathrm{P}_{\mathrm{CO}_{2}}$ (Tab. II), and $\mathrm{pH}$ was statistically not significant.

\subsection{The correlation of the dip area with the fetal base excess}

In Fig. 1 the fall of fetal base excess (meq/1), i.e. the difference between the first and the second scalp blood sample and umbilical arterial sample, respectively for a varying period of time is plotted

Tab. II. Fetal and maternal parameter during the second stage of labor. The $\mathrm{pH}, \mathrm{P}_{\mathrm{CO}}$ and base excess of the maternal and fetal blood from the hyperemized scalp and earlobe, respectively and from the umbilical arterial and venous blood. The dip area of fetal heart rate and baseline fetal heart rate is also given.

$(\bar{x}=$ mean, $\mathrm{SD}=$ standard deviation, $\mathrm{n}=$ number of cases).

During the time of observation, the fetal acid base parameters changed significantly.

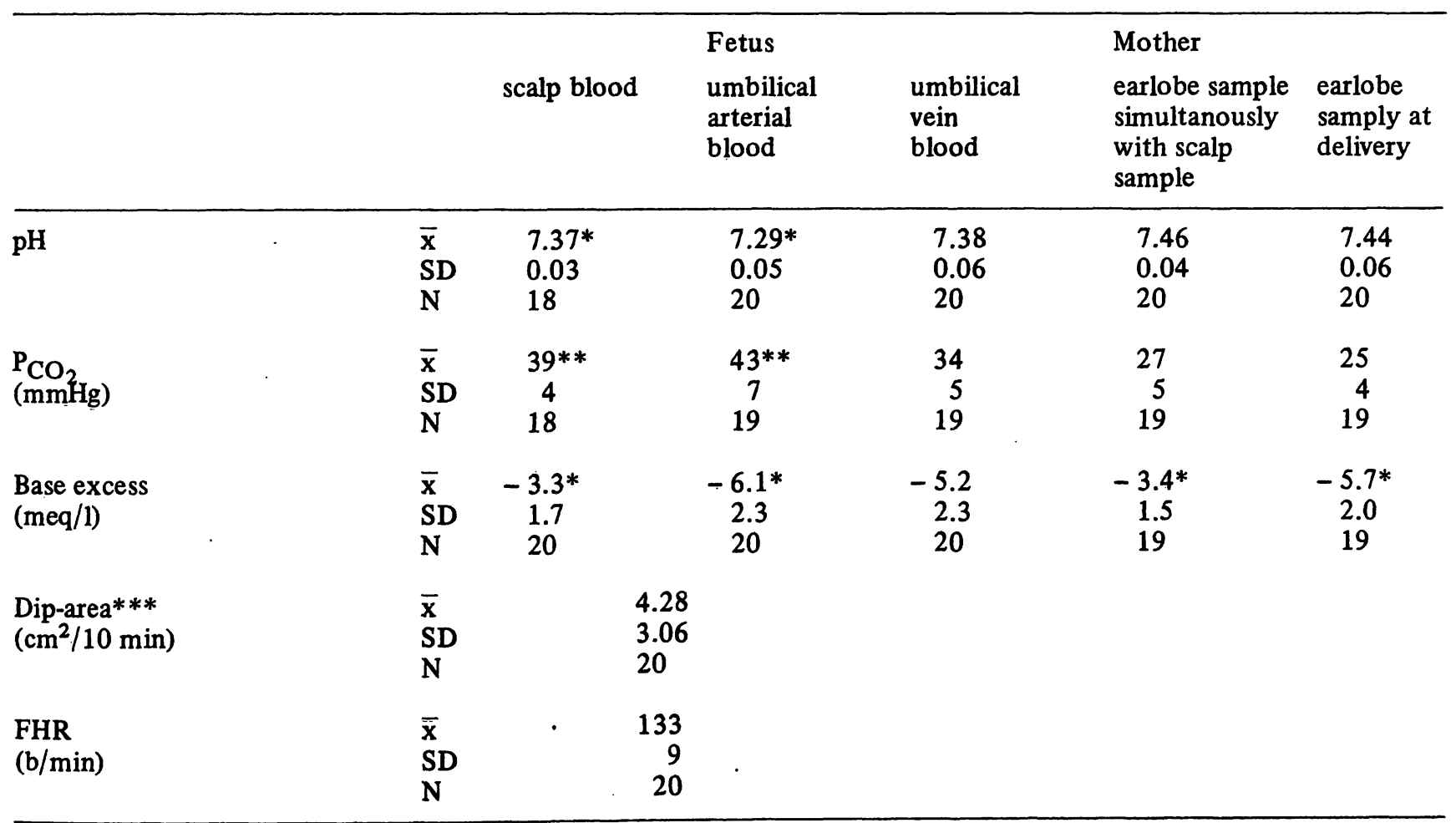

WILCOXON-test

$* 2 \alpha<0.01$

$* * 2 \alpha<0.05$

*** According to a record speed of $1 \mathrm{~cm} / \mathrm{min}$ on HEWLETT-PACKARD recording paper. 


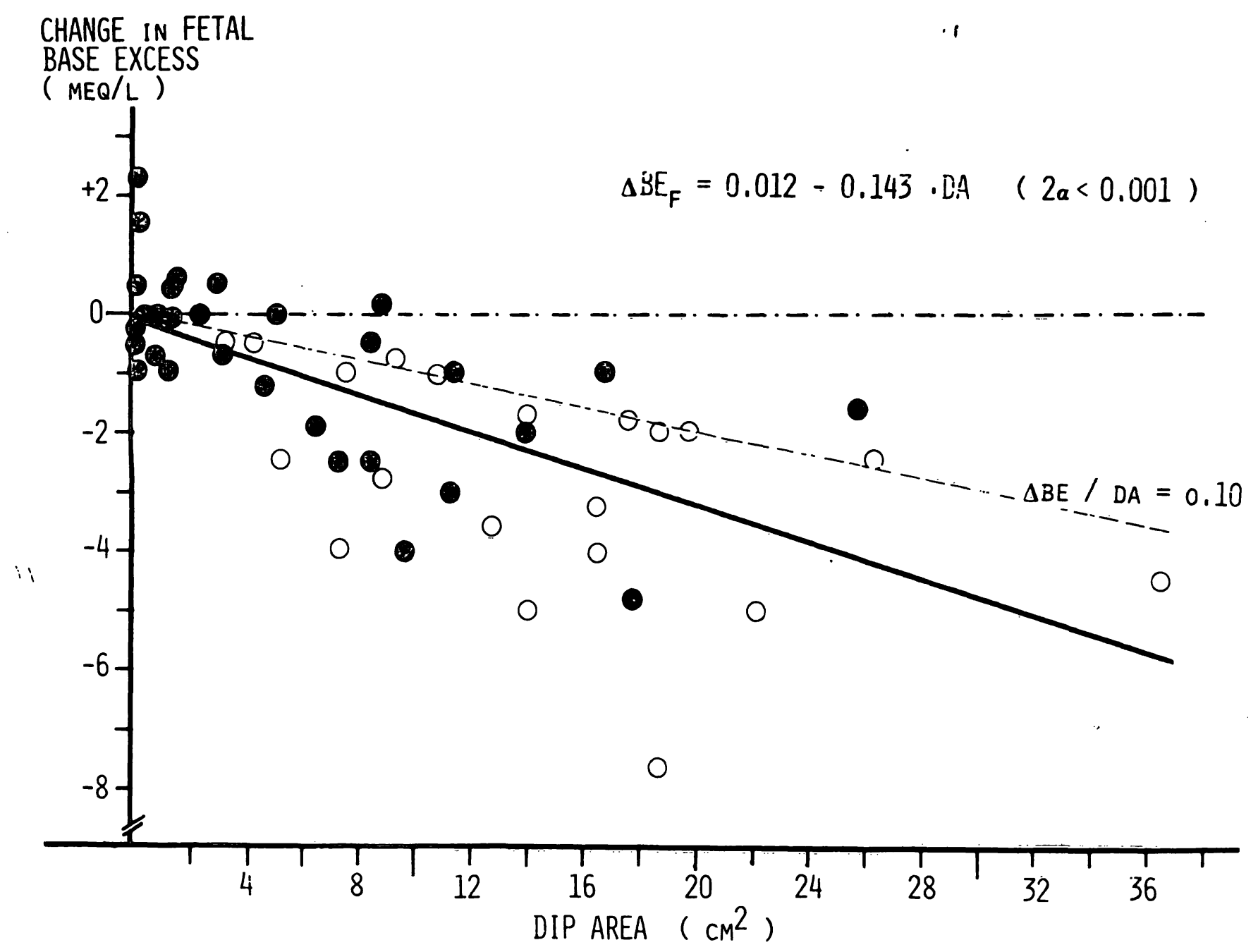

Fig. 1. The correlation between the decrease in fetal base excess (BE) and the dip area (BA) of fetal heart rate during the first stage of labor (dotts) and during the second stage of labor (open circles). There exists a significant relationship between both parameters, however the variance around the regression line is high especially when the diparea increases.

The small dotted line represents a line which demonstrates the fall of fetal base excess by a $\triangle B E / D A$ ratio of 0.10 i.e. if the fall in maternal $\mathrm{BE}$ is 0 , (see Fig. 3). The solid line is the calculated regression line for the first and the second stage of labor.

to the dip area, which was measured for the time of acid base observations. Because there is no difference in the correlation for the first (filled circles) and the second stage of labor (open circles) the entire measured data are given in one graph. The dip area is normal distributed as tested by means of probability paper. There exists a significant correlation of the DA with the change in fetal BE: change in $\mathrm{BE}=0.012-0.143$. DA $(2 \alpha$ $<0.01$ ). However it should be pointed out that the variance for the decrease in fetal base excess about the regression line increases if the DA grows (see also Tab. III).

This correlation shows, that for example, for a given dip area of $20 \mathrm{~cm}^{2}$ the fall in. base excess during the first, but also during the second stage of labor, has a range of $1.5 \mathrm{meq} / 1$ to $7 \mathrm{meq} / \mathrm{l}$. The graph shows also clearly that by a given dip area of less than $10 \mathrm{~cm}^{2}$ the fall in base excess never exceeds 4-5 meq/l. However it makes also clear that a DA of $20 \mathrm{~cm}^{2}$ is accompanied with a decrease in fetal $\mathrm{BE}$ of at least $1.5 \mathrm{meq} / 1$ and more. 
Tab. III. The alteration in fetal and maternal base excess related to the dip-area of fetal heart rate. Notice the increasing variance of the fall in fetal base excess with the increasing dip area. The increase is statistically significant.

(F-distribution; * $\alpha<0.05 ; * * \alpha<0.01$ ).

\begin{tabular}{|c|c|c|c|c|c|}
\hline \multicolumn{6}{|c|}{ Dip-area of fetal heart rate*** $\left(\mathrm{cm}^{2}\right)$} \\
\hline $\begin{array}{l}\text { range } \\
\text { mean } \\
\mathrm{SD} \\
\mathrm{N}\end{array}$ & & $\begin{array}{l}0-5 \\
1.61 \\
1.67 \\
20\end{array}$ & $\begin{array}{l}5.1-10 \\
7.91 \\
1.32 \\
11\end{array}$ & $\begin{array}{l}10.1-15 \\
12.57 \\
1.46 \\
7\end{array}$ & $\begin{array}{c}>15.1 \\
21.7 \\
5.90 \\
12\end{array}$ \\
\hline $\begin{array}{l}\text { Fall of fetal base excess } \\
\text { (meq/1) }\end{array}$ & $\begin{array}{l}\text { Mean } \\
\text { SD } \\
\mathbf{N}\end{array}$ & $\begin{array}{c}-0.30 \\
0.81 \\
20\end{array}$ & $\begin{array}{c}-2.02 \\
1.39 * \\
11\end{array}$ & $\begin{array}{l}-2.47 \\
1.48^{*} \\
7\end{array}$ & $\begin{array}{l}-3.34 \\
1.94 * * \\
12\end{array}$ \\
\hline $\begin{array}{l}\text { Fall of maternal base excess } \\
(\mathrm{meq} / \mathrm{l})\end{array}$ & $\begin{array}{l}\text { Mean } \\
\text { SD } \\
\mathbf{N}\end{array}$ & $\begin{array}{c}-0.48 \\
1.13 \\
20\end{array}$ & $\begin{array}{c}-1.46 \\
1.52 \\
11\end{array}$ & $\begin{array}{l}-2.25 \\
1.70 \\
6\end{array}$ & $\begin{array}{l}-2.10 \\
1.80 * \\
11\end{array}$ \\
\hline
\end{tabular}

*** according to a record speed of $1 \mathrm{~cm} / \mathrm{min}$ on HEWLETT-PACKARD recording paper

\subsection{The relationship between maternal and fetal base excess}

Fig. 2 shows the correlation of the decrease in the fetal base excess with the fall in maternal base excess during the first and second stage of labor. The different symbols indicate the dip-area which is grouped according to Tab. III in ranges with a DA of $0-5 \mathrm{~cm}^{2}$ (circles), $5.1-10 \mathrm{~cm}^{2}$ (squares) $10.1-15 \mathrm{~cm}^{2}$ (filled circels) and more than $15 \mathrm{~cm}^{2}$ (filled triangles). The dotted line is the relationship of both parameters that would exist if a given decrease in maternal base excess would be accompanied by the same drop in fetal base excess. 18 out of 48 cases show a close relationship to the fall of maternal base excess within a range of $\pm 0.5 \mathrm{meq} / \mathrm{l}$. However in 16 cases the drop in fetal base excess was more and in 14 cases less pronounced than in the maternal blood.

This correlation does not necessarily express that the fall in fetal BE is caused by changes in maternal BE. Both changes can occur in parallel however of different source (see comment). Therefore an attempt was made to estimate the influence of maternal BE upon the fetal acid base balance. For this purpose a factor (f) was calculated from the fall of fetal BE ( $\triangle \mathrm{FBE})$ and the measured DA: $\mathrm{f}=\Delta \mathrm{FBE} / \mathrm{DA}$. There exists a small, but significant correlation of the calculated factor with the change in maternal BE $(2 \alpha<0.05 ;$ Fig. 3$)$. The calculated
CHANGE IN FETAL

\section{BASE EXCESS}

(MEQ/L)

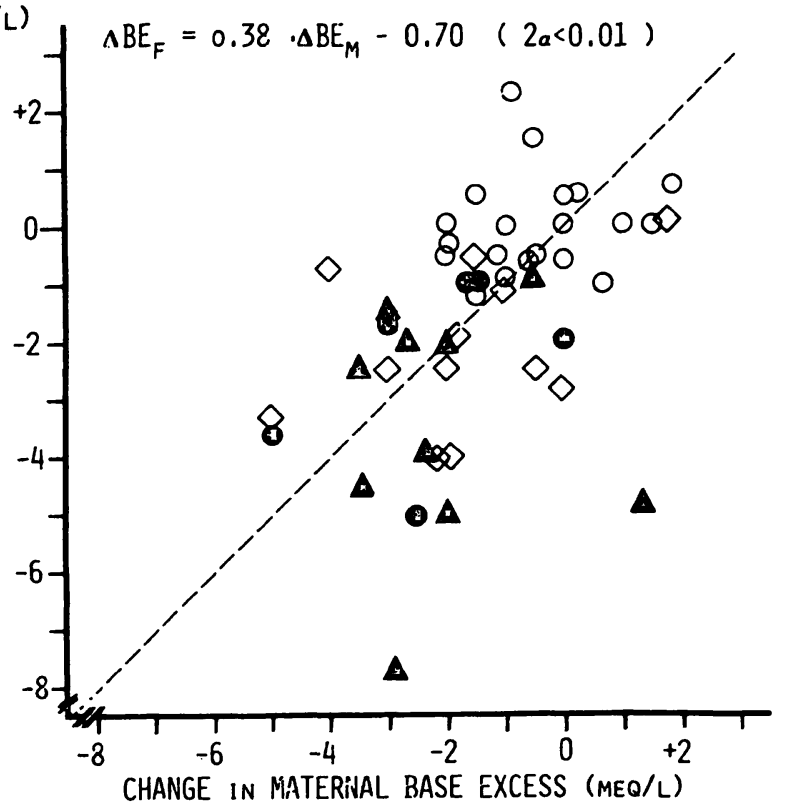

Fig. 2. The correlation between the rise or fall in fetal and maternal base excess (BE), respectively.

The different symbols indicate different ranges in the measured dip area (DA) during the first and second stage of labor. ODA $1.61 \mathrm{~cm}^{2}$ (SD 1.67, $\left.\mathrm{n}=20\right)$, 口DA $7.91 \mathrm{~cm}^{2}$

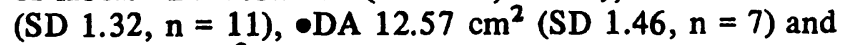
$\triangle D A 21.07 \mathrm{~cm}^{2}$ (SD 5.90, $\mathrm{n}=12$ ). The dotted line expresses the relationship between both parameters if a given decrease in maternal base excess would be followed by the same fall in fetal base excess. The significant relationship does not necessarily express a close connection between the fetal base excess and the maternal base excess. At the time where maternal base excess falls heart rate decelerations are also present. 


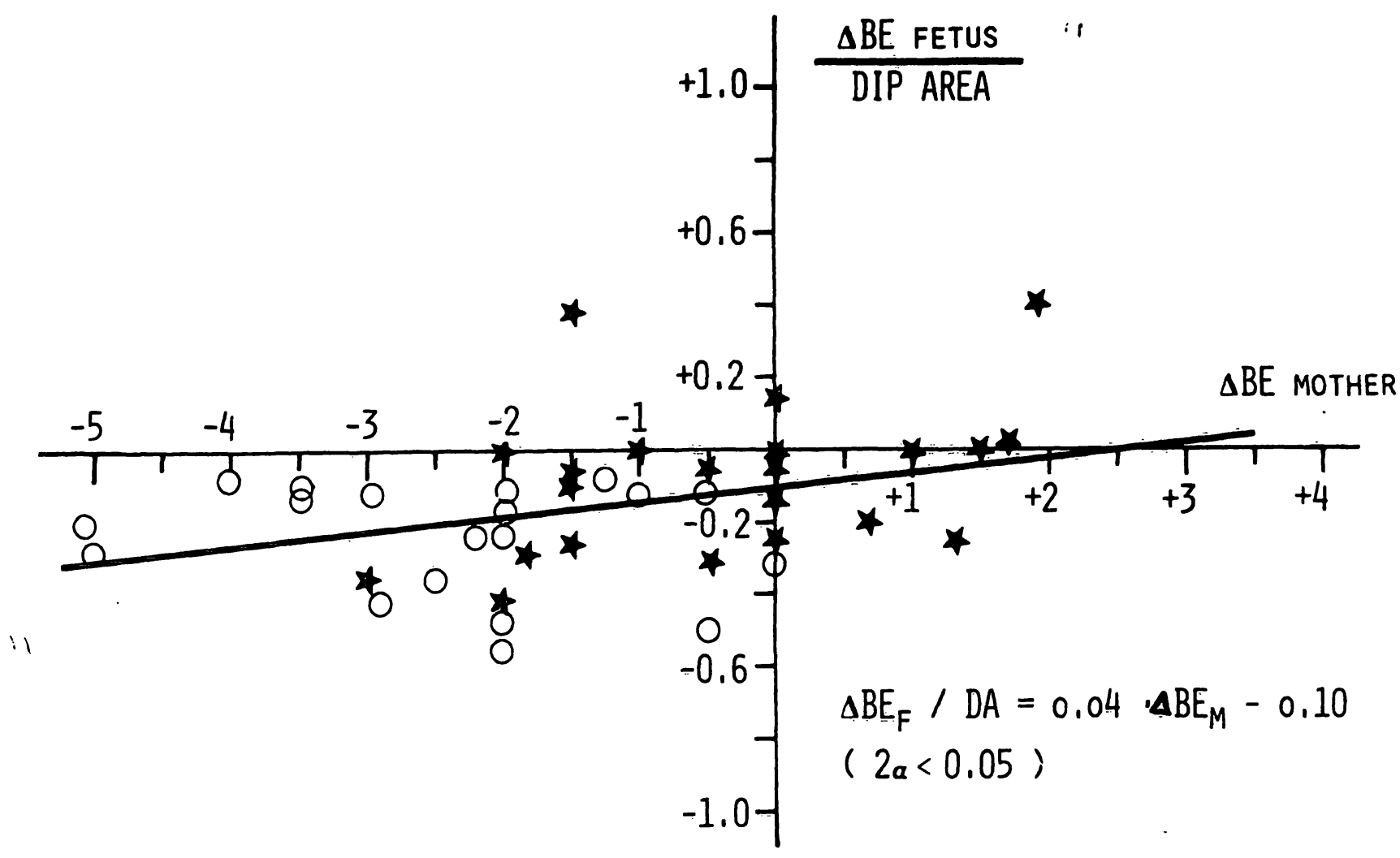

Fig. 3. The correlation between the change in fetal base excess per measured dip area $(\triangle B E / D A)$ related to the fall and increase of the maternal base excess, respectively.

The factor of fetal base excess and dip area should be almost constant if the fetal base excess is not altered by the maternal BE, however increase or fall, if lactate, which expresses mainly the changes in maternal BE, crosses the placenta from mother to the fetus or reverse. The stars are values achieved during the first stage of labor, the circles values from the second stage of labor. The correlation shows, that the fetal BE is additionally lowered if maternal BE falls.

factor decreases from -0.10 to -0.30 , if the maternal BE drops about 5 meq/l.

\section{Comments}

\subsection{Fetal base excess and dip area during the first and the second stage of labor}

Decelerations are combined with a decrease in fetal $\mathrm{P}_{\mathrm{O}_{2}}$ and $\mathrm{pH}$, a rise in $\mathrm{P}_{\mathrm{CO}_{2}}$ and a fall in base excess [5]. Since the fetal $\mathrm{P}_{\mathrm{CO}_{2}}$ and $\mathrm{pH}$ are easily affected by the maternal ventilation and even by the sampling technique we believe that the fetal condition is rather documented by the base excess than by the fetal pH. This is also shown in Fig. 4 were the change in base excess during the sample intervals is related to the change in fetal $\mathrm{pH}$. This figure shows a significant correlation between both parameters, however the variance in fetal $\mathrm{pH}$ about the regression line is related to changes in $\mathrm{P}_{\mathrm{CO}_{2}}$. Based on this consideration we used in our calculations the changes in fetal $\mathrm{BE}$.

The present results show with an increase in DA a drop of fetal base excess. There exists no difference in the relationship between these parameters whether they are measured during the first or during the second stage of labor. However, the fall in base excess will be much less during a period of $10 \mathrm{~min}$ in the first stage of labor $(\triangle B E$ $0.14 \mathrm{meq} / 1$ (SD 0.26) compared to the second stage of labor because the decelerations of fetal heart rate are not so frequently present (DA $\left.0.99 \mathrm{~cm}^{2} / 10 \mathrm{~min}\right)$. During the second stage of labor the DA increased up to $4.28 \mathrm{~cm}^{2} / 10 \mathrm{~min}$ (SD 3.06) and the fall in base excess increased to $0.76 \mathrm{meq} / 1 / 10 \mathrm{~min}$ (SD 0.62). The figure of 0.76 $\mathrm{meq} / 1 / 10 \mathrm{~min}$ differs from the previous reported value of $2.0 \mathrm{meq} / 1 / 10 \mathrm{~min}$ [3]. This difference is 


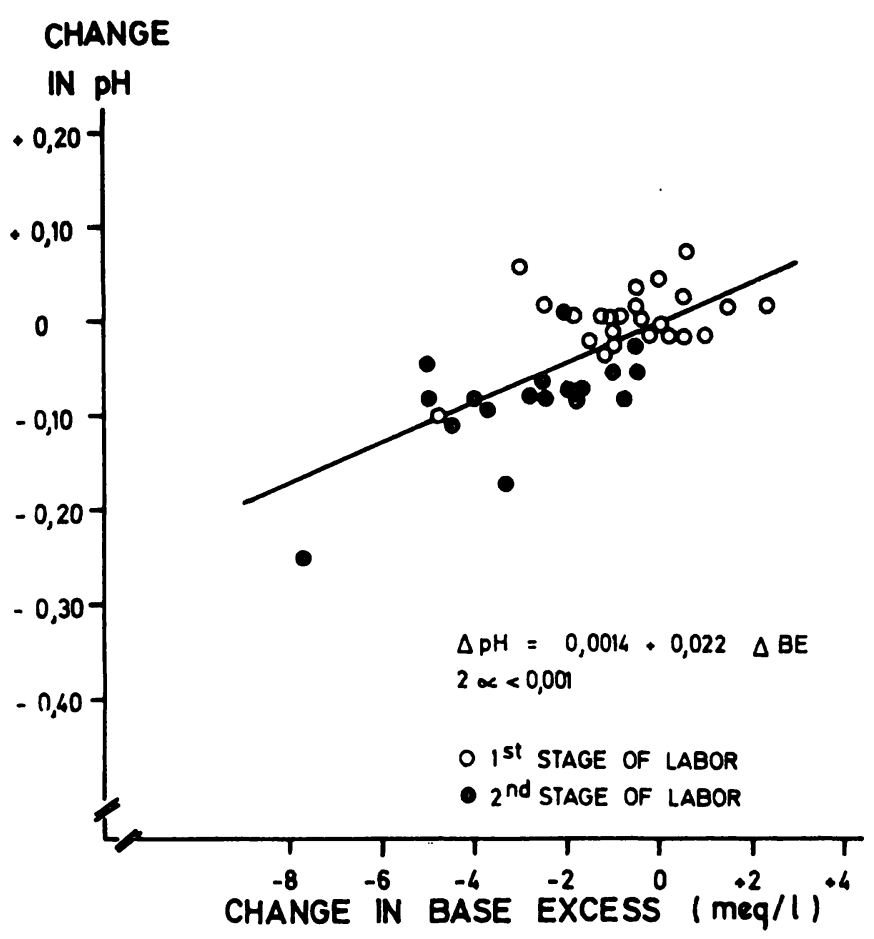

Fig. 4. The relationship between the change in $\mathrm{pH}$ and the change in base excess in the fetal blood during the first and the second stage of labor.

With a decrease in fetal base excess there is also a significant drop in fetal $\mathrm{pH}$.

due to a greater dip area related to the time the measurements were performed. The measurements in our previous experiments were carried out 26 min prior to delivery and in the present observations 41 min (SD 19) before birth of the baby.

\subsection{The variance of the fetal base excess by increasing dip area}

Fig. 1 and Tab. III show, that the variance of the drop in base excess increases, if the DA rises. For a given diparea of $20 \mathrm{~cm}^{2}$ f.e. the fetal base excess rises by about $1.5-2 \mathrm{meq} / \mathrm{l}$ up to $8 \mathrm{meq} / \mathrm{l}$. The stage of labor seems to be of less importance. The cause of this variance is not known. However the following hypotheses can be offered: Maternal influence: During labor maternal blood lactate rises and charges the fetal buffer base by crossing the placenta as suggested by WULF [11] and CAFFIER and WULF [17]. This observation receives some support by the experiments of PEARSON and
ShUtTleworth [6]. Maternal lactic acidemia induced by hypertonic fructose infusion into the mother was shown to cause a metabolic acidosis in the fetus. However the present results show (Fig. 2) that a fall in maternal base excess is not in every case accompanied by a proportional decrease in -fetal base excess (BE). In some cases the drop in fetal $\mathrm{BE}$ is less and more pronounced, respectively. This could be explained by recent observations concerning the transfer of lactic acid across the guinea-pig placenta. Lactic acid crosses the hemochoreal placenta in both directions [4].

In Fig. 3 an attempt was made to estimate the influence of the change in maternal BE on the fetal BE. A factor was calculated which expresses the relationship of the change in fetal $\mathrm{BE}$ and the simultanously measured DA. This factor would be constant if the fall in fetal BE is a close function of the DA and if there is no alteration by the maternal $\mathrm{BE}$, by the fetal-maternal lactic acid transfer or by influences such as fetal oxygenation. It would however increase and fall if the BE in the maternal blood would increase and fall respectively i.e. if lactic acid, which shows a close correlation to the $\mathrm{BE}$, crosses the placenta from the mother to the fetus and reverse. This correlation shows with $2 \alpha<0.05$ a small significance and seems to give some support that the fetal BE is altered by the maternal $\mathrm{BE}$. The fraction of the change in fetal $\mathrm{BE}$ to the DA is according to the calculated regression line -0.10 if the maternal $\mathrm{BE}$ is constant. This corresponds to the dotted line in Fig. 1. The fraction increases to -0.30 , if the maternal BE changes about $-5 \mathrm{meq} / \mathrm{l}$.

Fetal oxygenation: During each deceleration anaerobic glycolysis in the fetus takes place if a critical $\mathrm{O}_{2}$ saturation is achieved [5]. The accumulation of blood lactate and thus the fall in $\mathrm{BE}$ is most likely related to the duration of each decelerations. It seemed to be also dependent on the oxygen saturation at the respective time. However this statement needs further validation in an experimental model.

Baroreceptor - Response: Some decelerations may be generated by compression of the umbilical artery. This could be sufficient to reduce FHR via 
a presso-receptor response if umbilical blood flow is not reduced to such an extend that a severe hypoxia of the fetus is induced.

\section{Clinical significance}

Measuring the DA of FHR can be considered as a useful method to predict to some degree the fetal condition during labor. Concerning the present experiments there was no presence and development of fetal acidosis by normal baseline fetal heart rate if no heart rate alterations i.e. DA could be measured. It should be further taken into con- sideration that during the ifirst stage of labor as well as during the second stage of labor the fall in fetal BE by increasing DA is fairly equal however the fall in fetal BE per $10 \mathrm{~min}$. is more pronounced during the latter.

The increasing variance of the fall in fetal $\mathrm{BE}$ with increasing DA shows very clear that this method for exact prediction of fetal condition is limited. We feel therefore that measuring DA should be combined with fetal scalp blood sampling to have an exact statement. Both methods combined will give us informations in hand which facilitates the decision for operativ intervention.

\section{Summary}

The relationship between dip area (DA) of fetal heart rate (FHR) and the acid base status of fetus and mother during the first and second stage of labor were studied on 39 women at term.

The observations reveal a significant correlation between the fall in fetal base excess (BE) and the measured DA $: \Delta \mathrm{BE}=0.01-0.143 \mathrm{DA}(2 \alpha<0.01)$. There is no difference in the correlation of these parameters between the first and the second stage of labor, despite the fact of a greater fall in BE and a greater DA per time compared to the first: $B E \mathrm{meq} / 1 / 10 \mathrm{~min}$. 0.14 (SD 0.26) and 0.76 (SD 0.62); DA cm$/ 10 \mathrm{~min} .0 .99$ (SD 1.19) and 4.28 (SD 3.06), respectively.

With increasing DA the variance of the fall of fetal BE

$\left(S^{2}{ }_{B E}\right)$ rose also: $D A$ of $0-5 \mathrm{~cm}^{2}: \mathrm{S}^{2} \mathrm{BE} 0.66$; $\mathrm{DA}>15.1 \mathrm{~cm}^{2}: \mathrm{S}^{2} \mathrm{BE}$ 3.76. With the fall in fetal $\mathrm{BE}$ there was also a fall in maternal $\mathrm{BE}$, more pronounced during the second stage of labor: $-\mathrm{BE}_{\mathrm{F}}=0.38$. $\triangle \mathrm{BE}_{\mathrm{M}}$ $-0.70(2 \alpha<0.01)$.

The fraction of the fall in fetal BE per $\overline{\mathrm{D} A}$ increased with the fall in maternal $\mathrm{BE}(2 \alpha<0.05)$. This correlation reveals that there might be a slight influence of the maternal BE on fetal BE.

The present observation shows that measuring DA serves only as an appróach to predict fetal condition during labor. It therefore should be combined with fetal scalp blood sampling. The influence of maternal BE on fetal BE seems to be only of less importance.

Keywords: Acid-base-status, dip area, fetal heart rate, fetus, mother.

\section{Zusammenfassung}

Die Decelerationsfläche bei der Fetalen Herzfrequenz und ihre Beziehung zum Säurebasenstatus des Feten und der Mutter unter der Geburt.

Bei 39 Frauen am Termin wurde die Beziehung zwischen der Dezelerationsfläche (DF) der fetalen Herzfrequenz und dem fetalen mütterlichen Säurebasenstatus während der Eröffnungs- und Austreibungsperiode untersucht. Die Untersuchungen ergaben eine signifikante Korrelation zwischen dem Abfall des fetalen Basenexzesses (BE) und der gemessenen Dezelerationsflläche: $\triangle \mathrm{BE}=0.01-0.143$ DF $(2 \alpha<0.01)$. Es zeigte sich keine Differenz bei der Korrelation dieser Parameter zwischen der Eröffnungsperiode einerseits und der Austreibungsperiode andererseits, ausgenommen der Tatsache, daß der Basenexzess in der zweiten Periode stärker abfiel pro Zeiteinheit als in der Eröffnungsphase: $\mathrm{BE} \mathrm{meq} / \mathrm{l} / 10$ Minuten: 0.14 (SD 0.26 ) und 0.76 (SD 0.62); $\mathrm{DF} \mathrm{cm}^{2} / 10$ Minuten: 0.99 (SD 1.19) und 4.28 (SD 3.06).
Mit zunehmender Dezelerationsfläche nahm die Varianz des fetalen Basenexzessabfalles $\left(\mathrm{S}^{2} \mathrm{BE}\right.$ ) ebenfalls zu: DF von $0-5 \mathrm{~cm}^{2}: \mathrm{S}^{2}{ }_{\mathrm{BE}} 0.66 ; \mathrm{DF}>15.1 \mathrm{~cm}^{2}: \mathrm{S}^{2} \mathrm{BE}=3.76$. Mit Abfall des fetalen $B E$ ging auch ein Abfall des maternalen $B E$ einher; dies war ausgeprägter während der Austreibungsperiode: $\Delta \mathrm{BE}_{\mathrm{F}}=0.38 . \Delta \mathrm{BE}_{\mathrm{M}}=0.70(2 \alpha<0.01)$.

Der Anteil am Abfall des fetalen BE pro Dezelerationsflächeneinheit nahm zu mit dem Abfall des maternalen BE $(2 \alpha<0.05)$. Die Korrelation läßt die Vermutung $z u$, $\mathrm{daß}$ es eine leichte Beeinflußung des fetalen $\mathrm{BE}$ durch den maternalen geben könnte. Die vorliegende Beobachtung zeigt, daß das Ausmessen der DF lediglich als ein Versuch gelten kann, den fetalen Zustand unter der Geburt vorauszusagen. Er sollte daher mit fetalen Blutgasanalysen verbunden sein. Die Beeinfluß̣ung des fetalen BE durch die Mutter scheint von nur geringer Bedeutung zu sein. 
Résumé

Etude de la Dip-Area dans la fréquence cardiaque foetale et de ses relations avec les observations basoacidiques du foetus et de la mère pendant le travail

Le présent article porte sur l'étude de la relation entre la Dip-Area (DA) du Fetal Heart Rate (FHR) et le statut basoacidique du foetus et de la mère pendant les première et seconde phases du travail chez 39 femmes à terme.

Les observations ont montré une corrélation significative entre la baisse de l'excès basique foetal (BE0 et la DA mesurée: $\triangle \mathrm{BE}=0.01-0.143 \mathrm{DA}(2 \alpha<0.01)$. On n'a pas relevé de différence dans la corrélation de ces paramètres entre les première et seconde phases du travail malgré une baisse plus grande dans le BE et une plus grande DA par temps en comparaison avec les premiers résultats: respectivement $\mathrm{BE} \mathrm{meq} / 1 / 10 \mathrm{~min}$. 0.14 (SD 0.26) et 0.76 (SD 0.62); DA cm $/ 10$ min. 0.99 (SD 1.19) et 4.28 (SD 3.06).
En même temps qu'une hausse de la DA on observa un accroissement de la variation de la baisse du BE foetal $\left(S^{2}{ }_{B E}\right): D A$ de $0-5 \mathrm{~cm}^{2}: S^{2}{ }_{B E} 0.66 ; D A>15.1 \mathrm{~cm}^{2}$ : $\mathrm{S}^{2} \mathrm{BE}$ 3.76. A la baisse du $\mathrm{BE}$ foetal suivit parallèlement une baisse du $\mathrm{BE}$ maternel, plus prononcée pendant la seconde phase du travail: $\Delta \mathrm{BE}_{\mathrm{F}}=0.38$. $-\mathrm{BE}_{\mathrm{M}}-0.70$ $(2 \alpha<0.01)$.

La fraction de la baisse du BE foetal per DA a augmenté avec la baisse du BE maternel $(2 \alpha<0.05)$. Cette corrélation prouverait une légère influence du Be maternel sur le $\mathrm{BE}$ foetal.

Il est permis de conclure que la mesure de la DA peut seulement servir à préciser le pronostic de la condition foetale en cours de travail et qu'elle devrait être complétée par l'examen du sang épicrânien foetal. Le BE maternel semble n'avoir qu'une influence moins importante sur le BE foetal.

Mots-clés: Dip area, foetus, fréquence cardiaque foetale, mère, statut acido-basique.

\section{Bibliography}

[1] CAFFIER, H., H. WULF: Zur Frage einer Anaerobiose und Acidose des Feten unter der Geburt. Z. Geburtsh. Gynäkol. 166 (1967) 124

[2] CALDEYRO-BARCIA, R., C. CASACUBERTA, R. RUSTOS, G. GUISSI, L. GULIN, L. ESCARENCA, C. MENDEZ-BAUER: Correlation of intrapartum changes in fetal heart rate with fetal blood oxygen and acid-base-state. in: ADAMSONS, K.: Diagnosis and treatment of fetal disorders. Springer, Heidelberg 1967

[3] KASTENDIECK,E., W.KÜNZEL,P.ZIMMERMANN: Quantitative relationship between slowing of the fetal heart rate and changes in base-excess in the second stage of labor. J. Perinat. Med. 2 (1974) 106

[4] KASTENDIECK, E., W. MOLL: The transfer of lactic acid across theguinea-pig placenta. 5 th European Congress of Perinatal Medicine, Uppsala 1976

[5] KÜNZEL, W.: Die Beziehung zwischen Herzfrequenz des Feten und dem $\mathrm{P}_{\mathrm{O}_{2}}, \mathrm{P}_{\mathrm{CO}_{2}}$ und $\mathrm{pH}$ im fetalen Blut während der Eröffnungsperiode und am Ende der Austreibungsperiode. Z. Geburtsh. u. Perinat. 176 (1972) 275

[6] PeArson, J. F., R. SHUTTLEWORTH: The metabolic effects of a hypertonic fructose infusion on the mother and fetus during labor. Amer. J. Obstet. Gynec. 111 (1971) 259

[7] SHELLEY, T., R. TIPTON: Dip Area. A quantitative measure of fetal heart rate patterns. J. Obstet. Gynec. 78 (1971) 694

[8] TEJANI, N., L. I. MANN, A. BHAKTHAVATHSALAN, R. R. WEISS: A correlative study of fetal heart rate, uterine contraction patterns and fetal scalp blood pH. Amer. J. Obstet. Gynec. 46 (1975) 392

[9] TIPTON, R. H., T. SHELlEY: An index of fetal welfare in labour. Obstet. Gynec. 78 (1971) 702

[10] WULF, H., W. KÜNZEL, V. LEHMANN: Vergleichende Untersuchungen der aktuellen Blutgase und des Säure-Base-Status im fetalen und maternen Kapillarblut während der Geburt. Z. Geburtsh. Gynäk. 167 (1967) 113

[11] WULF, H.: A comparative study of actual blood gases and acid-base metabolism in maternal and fetal blood during parturition. In: HORSKY, J., Z. K. STEMBERA: Intrauterine dangers to the foetus. Excerpta Medica Foundation, Amsterdam 1967

Received March 3, 1976. Accepted July 13, 1976.

Prof. Dr. med. Wolfgang Künzel Universitäts-Frauenklinik, Würzburg Josef-Schneider-Str. 4 